\title{
THE POTENCY OF ALPHA LIPOIC ACID AS ANTI INFLAMMATORY ON THE COMPLETE FREUND'S ADJUVANT-INDUCED RHEUMATOID ARTHRITIS IN RAT MODEL
}

\author{
Selvi Megawati ${ }^{1}$, Mahardian Rahmadi ${ }^{2}$, Imam Susilo ${ }^{3}$, Junaidi Khotib ${ }^{2}$ \\ ${ }^{1}$ Magister Program of Pharmaceutical Science, Faculty of Pharmacy, Universitas Airlangga, Indonesia \\ ${ }^{2}$ Departement of Clinical Pharmacy, Faculty of Pharmacy, Universitas Airlangga, Indonesia \\ ${ }^{3}$ Departement of Pathological Anatomy, Faculty of Medicine, Universitas Airlangga, Indonesia
}

\begin{abstract}
ABSTRAK
Rheumatoid arthritis (RA) adalah penyakit autoimun yang ditandai dengan peradangan kronis dari jaringan sinovial pada sendi. Penelitian ini dirancang untuk menyelidiki efek dari alpha lipoic sebagai antioksidan pada tikus dengan lengkap Freund adjuvant (CFA) -diinduksi RA dengan suntikan artikular intra dari adjuvant lengkap Freund (CFA). ALA diberikan secara oral sekali sehari selama 7 hari pada 30, 60 dan 120 mg dosis seminggu setelah CFA injeksi. Tingkat keparahan arthritis dievaluasi dengan diameter bersama dan waktu latency pada stimulasi thermal. Joint diameter dan waktu latency pada stimulasi thermal akan diukur pada hari 0, 3, 5, 7, 10, 12 dan 14. Pengukuran malondialdehid (MDA) tingkat dalam plasma dilakukan dengan menggunakan metode asam thiobarbituric (TBA) untuk menilai peroksidasi lipid. Histologi sendi diperiksa dengan mikroskop berikut hematoxylin-eosin pewarnaan. Hasil penelitian menunjukkan bahwa pengobatan dengan ALA pada $30 \mathrm{mg}$ dan $60 \mathrm{mg}$ secara signifikan menurun diameter bersama dibandingkan dengan kelompok CFA ( $p=0,003 ; p=0,001$ masing-masing) dan waktu latency tikus pada stimulasi thermal juga secara signifikan meningkat dibandingkan kelompok CFA ( $p=0,015 ; p=0,026$ masing-masing). Pengukuran MDA dalam kelompok CFA dan kelompok ALA tidak memiliki perbedaan yang signifikan. Pewarnaan histologis menunjukkan bahwa pemulihan selaput sinovial dari sendi dalam kelompok ALA tidak berpengaruh. Hasil penelitian menunjukkan bahwa ALA memiliki efek untuk menekan perkembangan peradangan pada RA tetapi tidak melalui jalur stres oksidatif. (FMI 2016;52:98-103)
\end{abstract}

Kata kunci: arthritis rheumatoid, adjuvant lengkap Freund, alpha lipoic acid, antioksidan

\begin{abstract}
Rheumatoid arthritis (RA) is an autoimmune diseases which is characterized by chronic inflammation of the synovial tissue in joints. This research was designed to investigate the effect of alpha lipoic acid as antioxidant on rats with complete freund's adjuvant (CFA)-induced RA by intra articular injection of complete freund's adjuvant (CFA). ALA was administered orally once a day for 7 days at 30, 60 and $120 \mathrm{mg}$ doses a week after CFA injection. The severity of arthritis was evaluated by joint diameter and latency time on thermal stimulation. Joint diameter and latency time on thermal stimulation will measured on day 0, 3, 5, 7, 10, 12 and 14 . Measurement of malondialdehyde (MDA) level in plasma was performed using thiobarbituric acid (TBA) method to assess lipid peroxidation. Histology of joint was examined by microscope following hematoxylin-eosin staining. The result showed that treatment with ALA at $30 \mathrm{mg}$ and $60 \mathrm{mg}$ significantly decreased the joint diameter compared to CFA group ( $p=0.003 ; p=0.001$ respectively) and rat's latency time on thermal stimulation was also significantly increased compared to CFA group ( $p=0.015 ; p=0.026$ respectively). Measurement of MDA in CFA group and ALA group had no significant difference. Histological staining indicated that the recovery of the synovial membranes of joint in ALA group had no effect. Results indicated that ALA has the effect to suppress the development of inflammation in RA but not through oxidative stress pathway. (FMI 2016;52:98-103)
\end{abstract}

Keywords: Rheumatoid Arthritis, complete freund's adjuvant, alpha lipoic acid, antioxidant

Correspondence: Junaidi Khotib, Departement of Clinical Pharmacy, Faculty of Pharmacy, Universitas Airlangga, Kampus B Unair, Jl. Dharmawangsa Dalam, Surabaya 60286, East Java, Indonesia. e-mail address: junaidik@ff.unair.ac.id

\section{INTRODUCTION}

Rheumatoid arthritis (RA) is an autoimmune disorder that is characterized by chronic inflammatory of joints and effecting primarily synovial membrane. The cardinal features of RA include pain, swelling, morning stiffness (commonly more than an hour), warmth, redness. Additional features present include malaise, tiredness and night pain (Miossec \& Tebib 2006, Dubey \& Adebajo 2008, Orhan et al 2013). Prevalance of RA is $0.5-1 \%$ from population of world and increases at age 40 until 70 years (Saxena et al 2014, Wahl \& Schuna 2014).

Chronic inflammatory in RA produce cytokines such as tumor necrosis factor (TNF)- $\alpha$ and interleukin (IL)-1 
that leading to synovial fluid (Bhowmick et al 2008, Dubey et al 2008, Emery 2011). These cytokines bind to their receptors and activate the NFKB pathway. Activation of this pathways could produce matrix metalloproteinase (MMP) enzym. MMP is a destructive enzyme to joint and could be the trigger of RA (Malemud 2009, Waldburger \& Firestein 2009). IL-1 and TNF- $\alpha$ could also increase influx of neutrophils into synovial fluid. Neutrophils produces reactive oxygen species (ROS) by NADPH oxidase. ROS is a small molecule which has an unpaired electron that could attact polyunsaturated fatty acids (PUFA) and cause lipid peroxidation. Malondialdehyde (MDA) is a product of lipid peroxide-tion (Stadtman \& Baerlett 2002, Afonsu et al 2007, Ishibashi 2013). Even though the etiology of RA is not fully known yet, ROS had been suspected to play a role in RA. Report by Jaswal et al (2003) increasing levels of MDA have been found in RA patients and it was affected by the increasing of the ROS level.

An antioxidant could be involved in lowering the MDA level. Although endogenous antioxidant is a radical scavenger for ROS, when the number of endogenous antioxidants are not as many as radical scavengers exogenous antioxidant is required. ALA is one of the antioxidants having potential benefit in chronic disease. ALA is dithiol compound synthesized enzymatically in the mitochondrion from octanoic acid. It acts as a cofactor for mitochondrial $\alpha$-ketoacid dehydrogenases in energy metabolism. Now, it's marketed widely and used as a therapy for preventing and could be anti-inflammatory for diabetic polyneuropathy (Shay et al 2009, Golbidi et al 2011). To evaluate the potency of ALA as antioxidant therapy in RA, a rat model of RA was made by intra articular injection of CFA into the knee joint. Indicators of inflammation were evaluated by latency time on thermal stimulation that showed hyperalgesia and joint diameter to infer articular swelling. This study also measured MDA level as an indicator of oxidative stress and observed the changes of synovial membrane in the RA model by histophatology evaluation hematoxylin-eosin staining.

\section{MATERIALS AND METHODS}

\section{Materials}

$\alpha$-lipoic acid (ALA) were obtained from PT. Dexa Medika (Palembang, Indonesia), complete freund's adjuvant (CFA) (Sigma Aldrich), saline, 2-thiobarbituric acid (TBA) (Sigma-Aldrich). Reagents for MDA: trichloroacetic acid (TCA), $\mathrm{HCl}, \mathrm{NaOH}$ (Merck), TEP (TCI) and other reagents, such as propylene glycol, formaldehyde, and aquadest were obtained from PT. Bratachem (Surabaya, Indonesia).

\section{In vivo study}

8-12 weeks old male rats were used for the experiments. Rats were housed in individual cages and maintained under 12-hours light/dark cycle with food and water ad libitum. The animal were habituated to the apparatus before the onset of the experiments. The experimental procedures followed the guidelines for the care and use of laboratory animals and the study was approved by the Animal Ethics Committee, Faculty of Veterinary, Universitas Airlangga, Indonesia.

Rats were allocated randomly and divided into five groups, i.e saline $(n=6)$, CFA $(n=6)$, CFA-treated $(n=18)$ groups. As a rat model of RA, the rats were intraarticularly injected with $25 \mu \mathrm{L}$ of CFA and saline as a control. In the CFA-treated group, rats received 30, 60 and $120 \mathrm{mg} / \mathrm{kg}$ ALA orally. ALA was administered orally once a day for 7 days after a week of CFA administration. Rats were sacrificed on day 14. Blood was collected by venipuncture into EDTA. After centrifugation (3000 rpm for 25 minutes) plasma was immediately kept at $-20^{\circ} \mathrm{C}$. The joint were separated and kept in $10 \%$ neutral buffered formalin for 24 hours at room temperature.

Measurements were performed on day 0 (before any treatment) then on day $3,5,7,10,12$ and 14. Joint diameter was measured to infer joint swelling as an indicator of inflammation. Joint diameter was measured with manual caliper. For latency time on thermal stimulation, rats were placed on the hot plate with the temperature adjusted to $51,5^{\circ} \mathrm{C}$. The latency to the first paw licking, escape behavior (jump), rearing, tapping were taken as an index of nociceptive treshold.

Plasma MDA level was determined as thiobarbituric acid-reactive substances (TBARS) using spectrophotometer $\lambda 529 \mathrm{~nm}$. Briefly, $0.5 \mathrm{~mL}$ plasma was placed in $10 \mathrm{~mL}$ volumetric flash. Then, $0.5 \mathrm{~mL}$ TCA, $1.2 \mathrm{~mL}$ NaTBA $1 \%$, and $\mathrm{HCl} 0.1 \mathrm{~N}$ ad $10 \mathrm{~mL}$ were added. The tubes were mixed and incubated in a waterbath at $900 \mathrm{C}$ for 30 minutes followed by rapid cooling and then centrifuged at $3000 \mathrm{rpm}$ for $15 \mathrm{~min}$. The absorbance was measured photometrically at $529 \mathrm{~nm}$ in the supernatant and the concentrations were expressed as $\mu \mathrm{mol} / \mathrm{L}$.

Following sacrification, ankle joints were collected into $10 \%$ formalin solution for at least 24 hours before placement in decalcification solution containing EDTA 7.4 for 1 month, softening of the tissue was controlled by punching regularly. The tissues were embedded in parafin wax and sections were cut at $5 \mu \mathrm{m}$ thickness and 
stained with hematoxylin-eosin by routine procedures. Then, changes of histomorphological in the joints from CFA group compared to naive group.

Statistical snalysis

Values were expressed as means \pm standard deviation. One way ANOVA was performed to test the significance of the difference between the naive and ALA groups. When $\mathrm{F}$ values were found significant $(\mathrm{P}<0.05)$, Tukey's procedure for multiple range tests was then conducted.

\section{RESULTS}

\section{Joint diameter and hot plate test}

Signs of RA model were detected after CFA intra articular injection, it showed an increase in joint diameter and a decrease of latency time on thermal stimulation compared to naive group. Figure 1 and 2 showed a week after CFA induction, ALA administration orally once a day for 7 days improves the condition of RA which is characterized by a decrease in joint diameter and an increase of latency time on thermal stimulation. ALA at doses 30 and $60 \mathrm{mg} / \mathrm{kgBW}$ significantly decreased the ratio of joint diameter $(\mathrm{p}=0.003 ; \mathrm{p}=0.001$ respectively) compared to CFA group (fig.1). Latency time of ALA group on thermal stimulation was increased compared to CFA group (fig.2). The difference were observed on day 10 and 12 at dose $30 \mathrm{mg} / \mathrm{kgBW}$ ( $\mathrm{p}=0.039 ; \mathrm{p}=0.015$, respectively) and on day 12 ALA $60 \mathrm{mg} / \mathrm{kgBW}$ compared to CFA group $(\mathrm{p}=0.026)$.

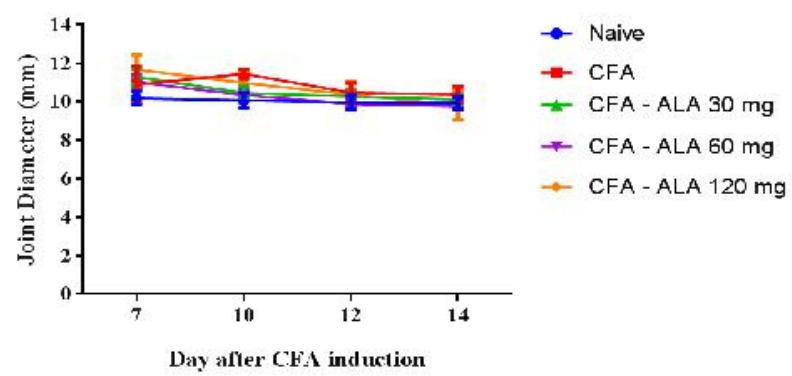

Fig. 1 Joint swelling assessed by measuring the joint diameter. CFA-induced rats showed an increased in joint diameter after injection. ALA administration orally once a day for 7 days at 30,60 or $120 \mathrm{mg} / \mathrm{kgBW}$ doses one week after CFA injection could decreased joint diameter.

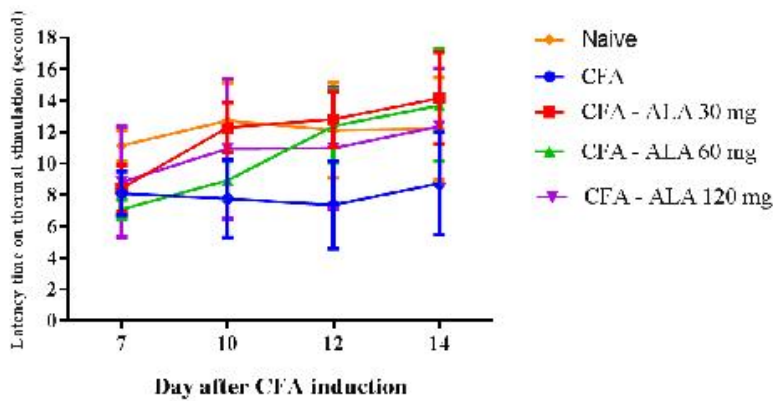

Fig. 2. Latency time on thermal stimulation as a sign of hyperalgesia. CFA-induced rats showed decreased in latency time on thermal stimulation after injection. ALA administration orally once a day for 7 days at 30,60 or $120 \mathrm{mg} / \mathrm{kgBW}$ doses one week after CFA injection could increased latency time on thermal stimulation.

\section{Plasma MDA level}

Lipid peroxidation was identified by MDA level. None of the groups receiving CFA injection and ALA administration (30, 60 and $120 \mathrm{mg} / \mathrm{kgBW})$ showed significant alterations in MDA level compared to the CFA group ( $p=0.989 ; p=0.999 ; p=1.000$, respectively).

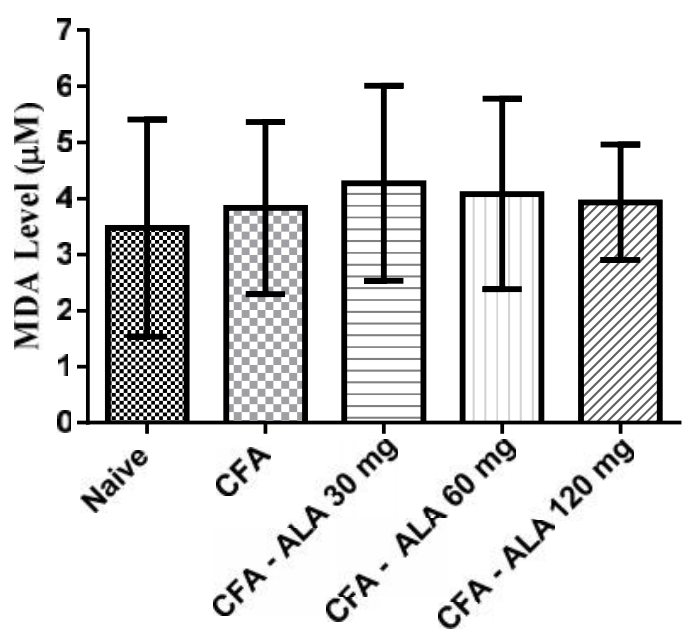

Fig. 3. Plasma MDA level in rats after CFA intra articular injection and ALA administration orally once a day for 7 days at 30,60 or 120 $\mathrm{mg} / \mathrm{kgBW}$ doses a week after CFA injection. Plasma MDA level was determined by TBARS method using spectrophotometer UV-Vis $\lambda 529$ $\mathrm{nm}$. 


\section{Effect of ALA on sinoviocyte proliferation}

Sinoviocyte proliferation in synovial membrane was observed by hematoxylin-eosin staining in all groups. Effect of ALA on sinoviocytes proliferation in rat's synovial membrane after CFA intra articular injection and ALA administration orally once a day for 7 days at 30,60 or $120 \mathrm{mg} / \mathrm{kgBW}$ doses one week after CFA injection in fig. 4 showed increased number of sinoviocyte in CFA group (panel B) compared to naive group (panel A). Panel C, D and E showed sinoviocyte in rats receiving ALA 30, 60 or $120 \mathrm{mg} / \mathrm{kgBW}$. In RA, proliferation sinoviocyte not only increased the number of syioviocytes but also adhered to the cartilage and aggravates the RA. The calculation of sinoviocyte in synovial lining was started from the intimal synovial layer. When these synoviocytes proliferates into the cartilage, the counting was started from the sinoviocyte cell's lining on the cartilage. Based on the number of sinoviocyte, ALA group at $30 \mathrm{mg} / \mathrm{kgBW}$ had less number of sinoviocyte compared to CFA group.

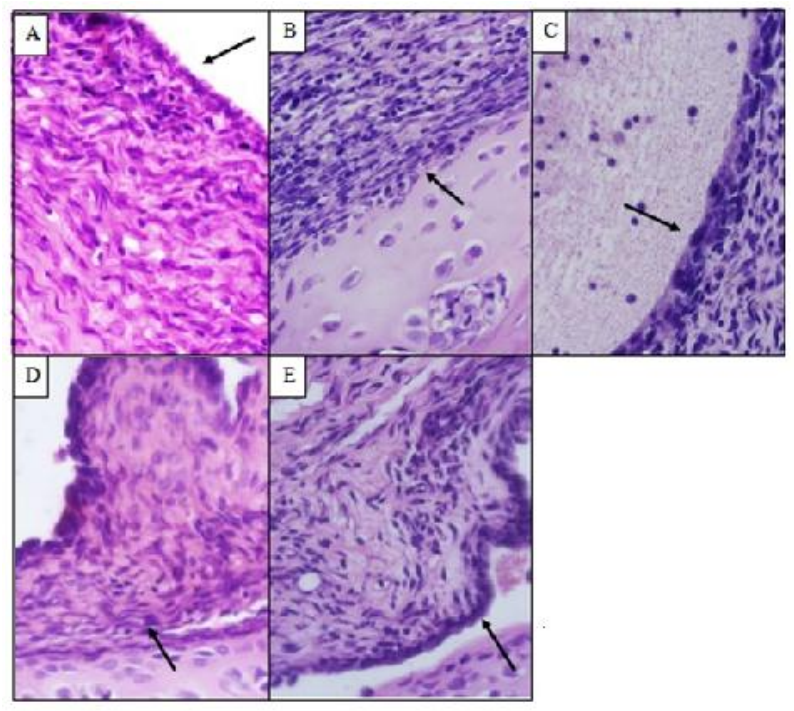

Fig. 4. The black arrows show sinoviocyte. (HE) staining for synovial membrane (magnification 1000x). (A) Naive group, (B) CFA group, (C) CFA-ALA30mg/kgBW,(D)CFA-ALA 60mg/ $\mathrm{kg}$ BW,(E)CFA-ALA120mg/kgBW

\section{DISCUSSION}

The RA model should not only induce relevant nociceptive behavior but also mimic as closely as possible the structural articular changes observed in the human RA disease. CFA intra articular injection leads to the development of RA as seen in human (Zhang \& Ren
2011, Snekhalatha et al 2012). Chen et al (2012) reported that CFA successfully induced RA in 100\% (10 of 10) of the injected rats. The result of latency time on thermal stimulation and joint diameter evaluation revealed that intra articular injection of CFA induced hyperalgesia and articular swelling in rats. These are the results of CFA contains Mycrobacterium butyricum and it could be the most potent initiator to activate the immune system. CFA induces secretion of cytokines so TNF- $\alpha$ and IL- 1 are released. These cytokines bind to their receptors and activate $\mathrm{NF} \kappa \mathrm{B}$ pathway and produce matrix metalloproteinase (MMP). MMP is a destructive enzyme to joints and could be the trigger of RA (Malemud 2009, Waldburger \& Firestein 2009). In ALA group, the joints diameter was decreased and latencty time on thermal stimulation was increased. It is because ALA could inhibit NFkB activation through inhibition of IKK2. IKK2 is essential for $\mathrm{I} \kappa \mathrm{B} \alpha$ degradation and subsequent $\mathrm{NF} \kappa \mathrm{B}$ activation because $\mathrm{I} \kappa \mathrm{B} \alpha$ degradation is a critical step for $\mathrm{NF} \kappa \mathrm{B}$ activation in response to TNF- $\alpha$ stimulation, the process of degradation mediates the migration of $\mathrm{NF} \kappa \mathrm{B}$ from cytoplasma into the nucleus.

In the development of inflammation in RA, cytokines also increase the influx of neutrophils. Neutrophil produces ROS and the role of increased oxidative stress in the development of chronic disease is a subject of great interest. Previous reports also indicate the role of oxidative stress in the pathogenesis of RA (Mirshafiey \& Mohsenzadegan 2008). Unexpectedly, the present study the value of MDA level as an indicator of lipid peroxidation showed no significant difference in CFA group compared to naive group. ALA which is known as potent antioxidant, did not significantly change plasma level of MDA. There was also no significant different between MDA level among the different experimental group. This strongly suggested that the mechanism of ALA may affect both oxidative stress and inflammatory process simulataneously through the inhibition of NFKB (Shay et al 2009, Mirtaheri et al 2015). Cytokines such as TNF $\alpha$ and IL are not only

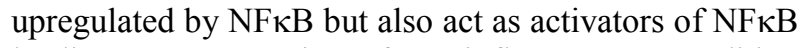
leading to perpetuation of pro-inflammatory condition (Malemud 2009, Waldburger \& Firestein 2009). Furthermore, ROS also known as considerable cause for oxidative stress in RA plays an essential role as both upstream and downstream pathways of NFKB. These intricate interactions form a positive feedback loop in which oxidative stress and inflammation amplify each other mutually (Henrotin et al 2003). Hence, ALA could interrupt these interaction via inhibiting $\mathrm{NF \kappa B}$. Contradictory to this present study there was no correlation between oxidative stress and RA. ALA 
could inhibit NFKB activation through anti-oxidantindependent mechanism.

This present study, histopathology evaluation by hematoxylin eosin staining indicated that there was an increased number of sinoviocyte in the synovial membrane of the CFA group. The earliest changes occur in the synovial membrane, leading to sinoviocyte proliferation. Sinoviocyte proliferation occurs in the surface of the membrane. When the condition continues, this leads to the thickening of synovial membrane (Capitanescu et al 2011). Sinoviocytes play critical roles in normal joint homeostatis. It secretes high-levels of long-chain, polymeric hyaluronan into joint cavity and controls the volume of the synovial fluid, which has both lubricating and immunomodulatory properties. But, the increasing number of sinoviocyte can stimulate inflammation in the joint of RA (Mor et al 2005). In ALA $30 \mathrm{mg} / \mathrm{kgBW}$ group, number of synoviocytes observed was not as many as the observation in CFA group or the other ALA groups. But, sinoviocytes were still higher than the number of sinoviocyte on the naive group because when inflammation occured the intra articular pressure rises sufficiently to inhibit blood flow into the synovial membrane whereas the inflammatory cells can still infiltrate into the joint cavity (Haywood \& Walsh 2001).

\section{CONCLUSION}

ALA has a potential effect for suppressing the development of inflammation in RA but not through oxidative stress pathway.

\section{REFERENCES}

Afonso V, Champy R, Mitrovic D, Collin P, Lomri A (2007). Reactive oxygen species and superoxide dismutases: role in joint diseases. Joint Bone Spine 74, 324-329

Bhowmick K, Chakraborti G, Gudi NS, Moideen AVK, Sheety HV (2008). Free radical and antioxidant status in rheumatoid arthritis. Indian Journal of Rheumatology 3, 8-12

Capitanescu B, Simionescu C, Margaritesu C, Stepan A, Ciurea R (2011). Clinical and morphological aspects of sinovitis early rheumatoid arthritis. Current Health Sciences Journal 37, 17-20

Chen L, Bao B, Wang N, Xie J, Wu W (2012). oral administration of shark type ii collagen suppresss complete freund's adjuvant-induced rheumatoid arthritis in rats. Pharmaceuticals 5, 339-352

Dubey S and Adebajo AO (2008). Historical and current perspectives on management of osteorthritis and rheumatoid arthritis. In: Reid DM and Miller CG (eds). Clinical Trials in Rheumatoid Arthritis and Osteoarthritis, London, Springe, p 12-13

Emery P (2011). Pocket Reference to Early Rheumatoid Arthritis, London, Springer Healthcare, p 1-4

Golbidi S, Badran M, Laher I (2011). Diabetes and alpha lipoic acid. Frontiers in Pharmacology 2, 1-15

Haywood L and Walsh D (2001). Vasculature of the normal and arthritis synovial joint. Histology and Histopathology Cellular and Molecular Biology 16, 277-284

Henrotin YE, Bruckner P, Pujol JPL (2003). The role of reactive oxygen species in homeostasis and degradation of cartilage. Osteoarthritis and Cartilage $11,747-755$

Ishibashi $\mathrm{T}$ (2013). Molecular hydrogen: new antioxidant and anti-inflammatory therapy for rheumatoid arthritis and related diseases. Current Pharmaceutical Design 19, 6375-6381

Jaswal S, Mehta HC, Sood AK, Kaur J (2003). Antioxidant status in rheumatoid arthritis and role of antioxidant therapy. Clinica Chimica Acta 338, 123129

Malemud CJ (2009). Intracellular signaling pathways in rheumatoid arthritis. Journal of Clinical and Cellular Immunology 4, 1-15

Miossec P and Tebib J (2006). Diagnosis of rheumatoid arthritis at an early stage. In: Bouysset $\mathrm{M}$, Tourne $\mathrm{Y}$, Tillmann K (eds). Foot and Ankle in Rheumatoid Arthritis, Berlin, Springer-Verlag, p 1-3

Mirshafiey A and Mohsenzadegan M (2008). The role of reactive oxygen species in immunopathogenesis of rheumatoid arthritis. Iranian Journal of Allergy, Asthma and Immunology 4, 195-202

Mirtaheri E, Gargari BP, Kolahi S, Dehghan P, AsghariJafarabadi M, Hajalilou M, Novin ZS, Abbasi MM (2015). Effects of alpha lipoic acid supplemetation on inflammatory biomarkers and matrix metalloproteinase-3 in rheumatoid arthritis patiens. Journal of the American College of Nutrition 34, 310317

Mor A, Abramson SB, Pillinger MH (2005). The fibroblast-like synovial cell in rheumatoid arthritis: a key player in inflammation and joint destruction. Clinical Immunology 115, 118-128

Orhan CE, Onal A, Uyanikgil Y, Ulker S (2013). Antihyperalgesic and antiallodynic effect of sirolimus in rat model of adjuvant arthritis. European Journal of Pharmacology 705, 35-41

Saxena R (2014). Arthritis as a disease of aging and changes in antioxidant status. In: Preedy VR (ed). Aging: Oxidative Stress and Dietary Antioxidants, London, Academic Press, p 52

Shay KP, Moreau RF, Smith EJ, Smith AR, Hagen TM (2009). Alpha-lipoic acid as a dietary supplement: molecular mechanisms and therapeutic potential. 
Biochimica et Biophysica Acta (BBA)-General Subjects 1790, 1149-1160

Snekhalatha U, Anburajan M, Venkatraman B, Menaka M (2012). Evaluation of complete freund's adjuvantinduced arthritis in a wistar rat model (comparison of thermography and histopathology). Zeitschrift für Rheumatologie 4, 375-382

Stadtman ER and Berlett BS (2002). Reactive oxygenmediated protein oxidation in aging and disease. In: Gilbert DL and Colton CA (eds). Reactive Oxygen Species in Biology Systems: An Interdisciplinary Approach, New York, Kluwer Academic Publishers, p 660
Wahl K and Schuna AA (2014). Rheumatoid arthritis. In: Dipiro JT, Talbert RL, Yee GC, Matzke GR, Wells BG, Posey LM (eds). Pharmacotherapy: A Pathophysiologic Approach, New York, Mc Graw Hill, p 3201-3203

Waldburger J and Firestein GS (2009). Signaling pathways in rheumatoid arthritis. In: Tak P (ed). New Therapeutic Targets in Rheumatoid Arthritis, Switzerland, Birkhauser Verlag, p 167-168

Zhang $\mathrm{R}$ and Ren K (2011). Animal models of inflammatory pain. In: Ma C and Zhang J (eds). Animal Models of Pain, London, Humana Press, p 2330 